University of Nebraska - Lincoln

DigitalCommons@University of Nebraska - Lincoln

USDA National Wildlife Research Center - Staff Publications
U.S. Department of Agriculture: Animal and Plant Health Inspection Service

2011

\title{
Effectiveness of AV-1011® to Reduce Damage to Drill-Planted Rice From Blackbirds
}

John L. Cummings

National Wildlife Research Center, john.I.cummings@aphis.usda.gov

Robert W. Byrd

U.S. Department of Agriculture

William R. Eddleman

Southeast Missouri State University

Richard M. Engeman

USDA-APHIS-Wildlife Services, s_r100@yahoo.com

Shelagh K. Tupper

National Wildlife Research Center

Follow this and additional works at: https://digitalcommons.unl.edu/icwdm_usdanwrc

Cummings, John L.; Byrd, Robert W.; Eddleman, William R.; Engeman, Richard M.; and Tupper, Shelagh K., "Effectiveness of AV-1011® to Reduce Damage to Drill-Planted Rice From Blackbirds" (2011). USDA National Wildlife Research Center - Staff Publications. 1297.

https://digitalcommons.unl.edu/icwdm_usdanwrc/1297

This Article is brought to you for free and open access by the U.S. Department of Agriculture: Animal and Plant Health Inspection Service at DigitalCommons@University of Nebraska - Lincoln. It has been accepted for inclusion in USDA National Wildlife Research Center - Staff Publications by an authorized administrator of DigitalCommons@University of Nebraska - Lincoln. 


\title{
Effectiveness of AV-1011 ${ }^{\circledR}$ to Reduce Damage to Drill-Planted Rice From Blackbirds
}

\author{
JOHN L. CUMMINGS, ${ }^{1}$ National Wildlife Research Center, U.S. Department of Agriculture, Animal and Plant Health Inspection Service, Wildlife \\ Services, 4101 LaPorte Avenue, Fort Collins, CO 80521-2154, USA \\ ROBERT W. BYRD, U.S. Department of Agriculture, Animal and Plant Health Inspection Service, Wildlife Services, P.O. Box 160, Portageville, \\ MO 63873, USA \\ WILLIAM R. EDDLEMAN, Department of Biology, Southeast Missouri State University, MS6200, Cape Girardeau, MO 63701, USA \\ RICHARD M. ENGEMAN, National Wildlife Research Center, U.S. Department of Agriculture, Animal and Plant Health Inspection Service, \\ Wildlife Services, 4101 LaPorte Avenue, Fort Collins, CO 80521-2154, USA \\ SHELAGH K. TUPPER, National Wildlife Research Center, U.S. Department of Agriculture, Animal and Plant Health Inspection Service, Wildife \\ Services, 4101 LaPorte Avenue, Fort Collins, CO 80521-2154, USA
}

\begin{abstract}
We determined efficacy of AV-1011 ${ }^{\circledR}$ (a 50\% anthraquinone product; Arkion ${ }^{\circledR}$ Life Sciences, New Castle, Delaware) on drill-planted rice seed to reduce blackbird damage and determine residue levels of anthraquinone (AQ) in rice seeds and seedlings and in the mature rice crop under field enclosures at the University of Missouri-Delta Center farm near Portageville, Missouri. Red-winged blackbird (Agelaius phoeniceus) damage was higher for untreated than $\mathrm{AV}-1011^{\mathbb{R}}$ treated rice seedlings at assessment period 3, 15 days postplanting $\left(F_{1,141}=15.81, P<0.001\right)$, and at assessment period 4,19 days postplanting $\left(F_{1,136}=11.54, P=0.001\right)$. Blackbird damage to AV-1011-treated seedling for assessment periods 3 and 4 was $8 \%$ and $7 \%$, respectively, while blackbird damage to untreated seedlings during the same assessment periods was 52\% and 44\%. More blackbirds used untreated plots than AV-1011-treated plots during assessment periods $2-4\left(F_{1,17.8}=20.02, P<0.001\right)$. Overall concentrations of AQ on seeds averaged $5,993 \mu \mathrm{g} / \mathrm{g}$ or $0.59 \%$ during the test period. Concentrations of AQ in mature rice seed and plant collected at harvest averaged $1.22 \mu \mathrm{g} / \mathrm{g}$ and $0.10 \mu \mathrm{g} / \mathrm{g}$, respectively. AV-1011 offers promise for reducing bird depredations to newly planted rice, but additional testing should be conducted to evaluate this repellent in a large-scale field setting. (C) 2011 The Wildlife Society.
\end{abstract}

KEY WORDS Agelaius phoeniceus, anthraquinone, AV-1011 ${ }^{\mathbb{R}}$, birds, bird repellent, blackbirds, rice, seedling damage, wildlife damage management.

Rice is an important economic crop in Arkansas, California, Louisiana, Missouri, Mississippi, and Texas with approximately 203,733,000 hundred weight (cwt) in production and a value of $\$ 3.6$ billion in 2008 (United States Department of Agriculture [USDA], National Agricultural Statistics Service 2008). Red-winged blackbirds (Agelaius phoeniceus), common grackles (Quiscalus quiscula), and brown headed cowbirds (Molothrus ater) cause extensive damage to newly planted rice and ripening rice in several areas of these rice producing states (Cummings et al. 2002). Estimated economic loss to the rice industry in Arkansas, California, Louisiana, Missouri, and Texas during 2002 from blackbirds due to direct damage, prevention, and lost price support has been estimated at \$21.5 million (Cummings et al. 2005). Economic loss in 2008 was estimated at $\$ 38.1$ million based on the 2008 value of the crop (S.A. Shwiff, USDA, personal communication). Various federal, state and local agencies, and rice growers associations consider resolving blackbird damage to rice a high priority.

Rice growers employ several methods to alleviate blackbird damage, such as habitat manipulation, mechanical and

Received: 13 January 2010; Accepted: 19 July 2010

${ }^{1}$ E-mail: john.l.cummings@aphis.usda.gov pyrotechnic devices, and shooting (Dolbeer et al. 1994). Few stakeholders believe these methods are effective or logistically practical. The ineffectiveness of current management tools has stimulated efforts to develop an effective, economical, and environmentally safe chemical repellent (Cummings et al. 1992, 1994; Werner et al. 2008a,b). One such chemical is anthraquinone (AQ), which is a naturally occurring compound found throughout the plant kingdom and first patented in 1944 as a bird repellent. It occurs in many invertebrates and some appear to have a predator defense function (Hilker and Kopf 1994). Its bird-deterrent capability has long been recognized and it is now registered and sold under the product name Flight Control ${ }^{\mathbb{R}}$ (Arkion ${ }^{\circledR}$ Life Sciences, New Castle, DE) as a feeding deterrent against geese on lawns and turf (Cummings et al. 2002). Results of controlled laboratory studies and smallscale field tests in water-seeded rice indicate that concentrations from $0.5 \%$ to $1.0 \% \mathrm{AQ}$ are effective in reducing rice consumption by blackbirds (Avery et al. 1998, Cummings et al. 2002). No definitive tests with AQ have been conducted on drill-planted rice.

In 2006 and 2007 the United States Environmental Protection Agency (EPA) approved an emergency use Section 18 application of AV-1011 ${ }^{\circledR}$ (Arkion Life 
Sciences) for use on corn in Michigan, Minnesota, and Wisconsin. Since then other states including Texas, South Dakota, Louisiana, and Mississippi have also gained approval under Section 18 for corn. In addition, Arkion Life Sciences has been pursuing EPA registration of AQ under the product name $\mathrm{AV}-1011^{\mathbb{}}$ (a $50 \%$ AQ product) to protect rice seed from bird depredations. We sought to determine the effectiveness of AV-1011 ${ }^{\circledR}$ as a blackbird repellent on drill-planted rice and to determine AQ residues in the rice plant and mature seeds.

\section{METHODS}

We selected a $2 \%$ concentration $(\mathrm{ml} / \mathrm{g})$ of $\mathrm{AV}-1011^{\circledR}(50 \%$ active ingredient $9,10 \mathrm{AQ}$ or a $1 \%$ active $\mathrm{AQ}$ ) based on earlier findings from field tests conducted on water-seeded rice in Louisiana (Cummings et al., 2002). Also we suspected that drill-planted rice might be vulnerable to blackbird damage for a longer period of time, 20-30 days, which would require a concentration that did not degrade below a repellency threshold of $1 \%$ product or $0.5 \%$ active AQ.

We evaluated the consumption of drill-planted rice treated with $2 \%(\mathrm{ml} / \mathrm{g}) \mathrm{AV}-1011^{\circledR}$ and untreated rice by red-winged blackbirds within 10 experimental enclosures, or netted plots (each $9.1 \mathrm{~m}$ long, $3.7 \mathrm{~m}$ wide). We planted rice seed in plots following normal drill planting practices to a depth of $2 \mathrm{~cm}$ into moist soil and enclosed 20 May 2008 at the University of Missouri-Delta Center farm near Portageville, Missouri. We established 2 subplots (each $4 \mathrm{~m}$ long, $3 \mathrm{~m}$ wide) within each plot. We randomly assigned treatments (treated and untreated) among subplots such that we planted one subplot with rice seed treated with $2 \% \mathrm{AV}-1011$ and one plot with untreated rice seed. We placed 5 male naivve red-winged blackbirds into each enclosure with unrestricted access to all subplots immediately following planting. We maintained 5 blackbirds in each enclosure with access to water ad libitum and maintenance food (300 g mixed bird seed). Water and food pans were centered within test enclosures throughout the study. The National Wildlife Research Center (NWRC) Institutional Animal Care and Use Committee approved capture, care, and use of birds associated with this study (NWRC Study Protocol QA1560).

We prepared treated seed rice by placing $4 \mathrm{~kg}$ of rice seed in a mixing container. As the mixing container rotated for $3 \mathrm{~min}$, we sprayed a water formulation containing $80 \mathrm{ml}$ of AV-1011 onto the rice. We placed AV-1011-treated rice under a drying hood for $24 \mathrm{hr}$ and then packaged it for planting. Additionally, we collected a $20 \mathrm{ml}$ sample of the AV-1011 formulation, a $20 \mathrm{~g}$ sample of $2 \% \mathrm{AV}$-1011-treated seed rice, and a $20 \mathrm{~g}$ sample of untreated rice for chemical analysis.

We determined blackbird consumption of AV-1011-treated rice and untreated rice by counting the number of seedlings remaining at 5 days interval starting 5 days postplanting (26 May 2008) and until the conclusion of the test, 19 days postplanting. Within each subplot, we randomly placed 4 screen exclosures $(30 \mathrm{~cm} \times 30 \mathrm{~cm} \times 10 \mathrm{~cm})$ over the same number of rows of planted rice seed to provide an estimate of undamaged seedling density. At each 5 day interval, we assessed consumption of rice seedlings by randomly placing a $30 \mathrm{~cm} \times 30 \mathrm{~cm}$ grid about $0.6 \mathrm{~m}$ from the exclosure to record the number of seedlings remaining. We marked grid corners with $4 \mathrm{~cm}$ wood markers so we could conduct subsequent assessments from the same fixed location. We analyzed blackbird damage to seeds and seedlings using a 3-factor factorial mixed model analysis of variance in a randomized block design. The 3 factors were treatments, exclosures or grids, and assessment period (SAS 2003).

We determined the germination rate of rice seed treated with 2\% AV-1011 and untreated rice seed prior to planting following the Association of Official Seed Analysis seed testing rules for rice (Association of Official Seed Analysts 1981). We placed 1010 -seed replicates of treated and untreated seed in a growth medium and monitored them under controlled greenhouse conditions at the University of Missouri's Delta Center, Portageville, Missouri. We recorded rice seed germination at 5 days and 14 days postplanting.

We conducted daily bird observations from 0630 to $1100 \mathrm{hr}$ during the test period to determine use of subplots by blackbirds. We recorded the number of blackbirds in each subplot each minute for a 10-min period. We conducted observations from the same location each day to reduce observation bias and minimize any influence on birds. We used a 2-factor factorial design to analyze bird observations; factors were treatments and days (SAS 2004).

We planted 2 additional plots adjacent to test enclosures to determine $A V-1011$ residues at various stages of rice plant growth. We followed the same procedures for planting treated and untreated rice seed in each plot. We collected rice seedling stages postplanting when susceptible to blackbird damage; we collected seedlings on 26 May (5 days postplanting), 30 May, 4 June, 9 June, and 14 October 2008 (harvest). These time periods reflect the stages when rice seedlings are most susceptible to blackbird damage. We collected $25 \mathrm{~g}$ samples from random locations in each plot, separated seeds from seedlings, and individually labeled samples before freezing and shipped them to the NWRC for processing and analysis (NWRC Method 102A, 107, 109B). At harvest, we collected $25 \mathrm{~g}$ sample of the entire plant above the roots and labeled, froze, and shipped samples to the NWRC for processing and analysis (NWRC Method 102, 107, 109B). Prior to analysis, we separated rice panicles from the plant and analyzed them separately.

\section{RESULTS}

At assessment period 1, 5 days postplanting, it was difficult to determine whether blackbirds had consumed any rice seeds because seedlings had not emerged above ground (Fig. 1). At assessment period 2, 10 days postplanting, seedlings started emerging and we detected some damage, however, it did not differ between treated and untreated plots (Fig. 1). At assessment period 3, 15 days postplanting, blackbirds damaged more untreated seedlings (52\%) than AV-1011-treated rice seedlings ( $8 \% ; F_{1,141}=15.81, P<0.001 ;$ Fig. 1$)$. At assessment period 4, 19 days postplanting, blackbirds damaged more untreated seedlings (44\%) than AV-1011-treated rice 


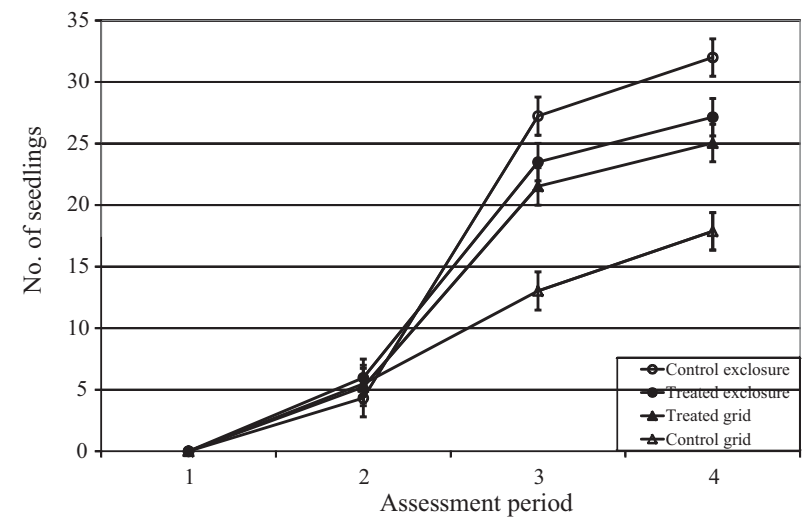

Figure 1. Rice seedlings remaining ( $\mathrm{X} \pm$ standard error) in treated $(2 \%$ AV- $1011^{\mathbb{R}} ; 0.97 \%$ active ingredient anthraquinone) and untreated plots exposed to red-winged blackbirds. We drill-planted plots at the University of Missouri-Delta Center, Portageville, Missouri, 20 May 2008. We also show the mean number of rice seeds or seedlings in treated and untreated plot exclosures. Capped vertical bars represent standard errors.

seedlings $\left(7 \% ; F_{1,136}=11.54, P=0.001\right.$; Fig. 1$)$. There was no difference between seedling counts in enclosures for $\mathrm{AV}-1011$ ( $x=23$ and 27, assessment periods 3 and 4, respectively) and untreated enclosures $(x=27$ and 32 , assessment periods 3 and 4, respectively) indicating that there were no phytotoxic effects to rice seedlings from the treatment. This lack of phytotoxic effects was verified by the results of the rice seed germination test, which showed no difference in the germination rate of rice seed treated with $2 \% \mathrm{AV}-1011$ (89.5\%) and untreated rice seed (92\%; $t=-0.81, P=0.423)$.

Bird counts among plots did not differ during the first assessment period (days 1-5 postplanting) before most rice seed germinated (Fig. 2). As seedlings emerged during assessment periods $2-4$, we counted more blackbirds using untreated plots than $\mathrm{AV}$-1011-treated plots $\left(F_{1,17.8}=\right.$ 20.02, $P<0.001$ ).

The amount of AQ in AV-1011 used to treat rice seed averaged $51.6 \%$. The target formulation concentration of AQ on rice seed was $1.0 \%$ at planting; the actual concentration of $\mathrm{AQ}$ on rice seed after treatment averaged $0.97 \pm 0.01 \%$. Concentrations of $\mathrm{AQ}$ on rice seed from seedlings collected each assessment period averaged $6,245 \mu \mathrm{g} / \mathrm{g}, 5,885 \mu \mathrm{g} / \mathrm{g}, 6,250 \mu \mathrm{g} / \mathrm{g}$, and $5,595 \mu \mathrm{g} / \mathrm{g}$ for 5 days, 10 days, 15 days, and 19 days postplanting, respectively. Overall concentrations of AQ on seeds averaged $5,993 \mu \mathrm{g} / \mathrm{g}$ or $0.59 \%$ during the test. Residues on all control samples were below the method limit of detection (MLOD; $\mathrm{MLOD}=4.91 \mu \mathrm{g} / \mathrm{g} \mathrm{AQ})$. Concentrations of $\mathrm{AQ}$ in rice seedlings collected 5 days, 10 days, 15 days, and 19 days postplanting averaged $14.4 \mu \mathrm{g} / \mathrm{g}, 13.5 \mu \mathrm{g} / \mathrm{g}, 12.5 \mu \mathrm{g} / \mathrm{g}$, and $26.8 \mu \mathrm{g} / \mathrm{g}$, respectively. All control rice seedling samples were below the limit of detection (MLOD $=4.91 \mu \mathrm{g} / \mathrm{g}$ $\mathrm{AQ}$. Concentrations of $\mathrm{AQ}$ on mature rice seed collected at harvest averaged $1.22 \mu \mathrm{g} / \mathrm{g}$, control samples were $<\mathrm{MLOD}=1.3 \mu \mathrm{g} / \mathrm{g} \quad \mathrm{AQ}$. Concentrations of $\mathrm{AQ}$ in mature rice plant collected at harvest averaged $0.10 \mu \mathrm{g} / \mathrm{g}$; control samples were $<\mathrm{MLOD}=0.077 \mu \mathrm{g} / \mathrm{g}$ AQ.

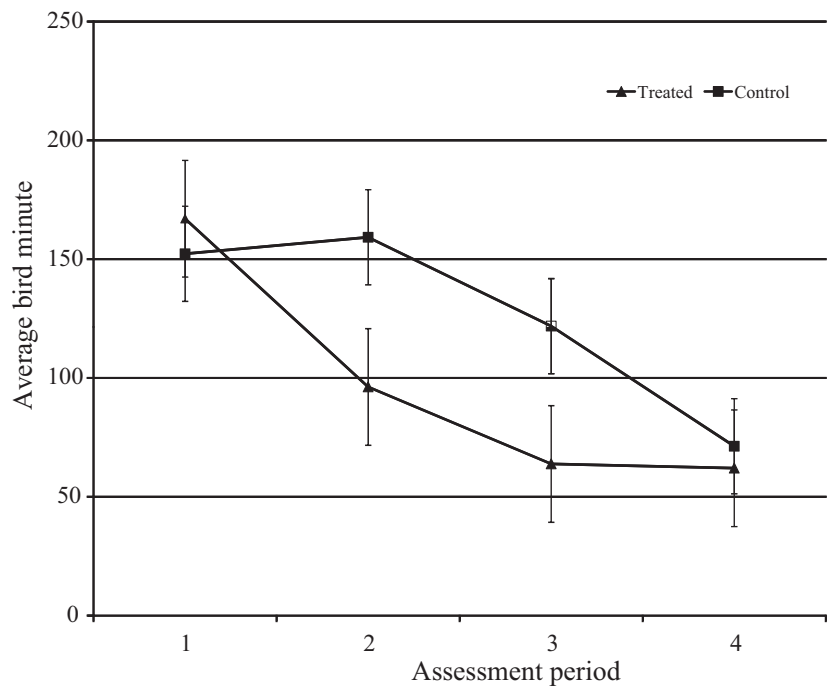

Figure 2. Red-winged blackbird use of treated $\left(2 \%\right.$ AV- $-1011^{\circledR} ; 0.97 \%$ active ingredient anthraquinone) and untreated plots. We drill-planted rice in plots at the University of Missouri-Delta Center, Portageville, Missouri, 20 May 2008. Capped vertical bars represent standard errors.

\section{DISCUSSION}

Small field test sites commonly used to meet the EPA's acreage limitation of $4 \mathrm{ha}$, together with the necessity of destroying the crop after the test, often make it difficult to evaluate bird repellents under ordinary conditions. Bird pressure is often unpredictable and too low to successfully evaluate a compound in such small plots. The enclosures we used ensured there would be bird pressure throughout the test, which allowed us to evaluate the repellent under what we considered severe conditions. The bird pressure in each enclosure during the trial was equivalent to about 1,800 redwinged blackbirds per ha per day. Under these conditions, bird damage to treated rice seedlings $(7 \%)$ was reduced by $84 \%$ compared with untreated seedling damage (44\%). Effectiveness of AV-1011 would probably be greater under normal conditions encountered in rice fields, where birds have alternative food and can move to alternative feeding sites.

The mechanism of repellency for AV-1011 (AQ) is not well understood (Avery et al. 1997, Avery 2002). Ingestion of AQ-treated food by birds can produce vomiting, presumably through irritation of the gut lining (Avery and Cummings 2003). Our preliminary observations support the findings that indicate ingestion of AQ may cause a slight sickness prompting an avoidance of treated seeds and seedlings (Avery et al. 1997, Avery 2002). Data submitted to the EPA suggests that AV-1011 poses no toxicological risk to birds or mammals (EPA 1998). The lethal dose $\left(\mathrm{LD}^{50}\right)$ is $>3,000 \mathrm{mg} / \mathrm{kg}$ for bobwhite quail (Colinus virginianus) and $>5,000 \mathrm{mg} / \mathrm{kg}$ for rats (Rattus norvegicus) and rabbits (Oryctolagus cuniculus). Damage assessments and bird observations seem to indicate that blackbirds that have consumed AV-1011 will avoid consuming it on repeated encounters. Bird observations indicate that AV-1011 caused site avoidance of treated subplots. 


\section{MANAGEMENT IMPLICATIONS}

Development of an effective chemical bird repellent for agriculture crops, especially rice, is an important economic issue. Our results demonstrated that AV-1011 can be a viable option for growers in reducing blackbird damage to newly drill-planted rice. Rice seeding application rates range from $28 \mathrm{~kg} / \mathrm{h}$ a for hybrid seed to $100 \mathrm{~kg} / \mathrm{h}$ for conventional seed, which would cost from $\$ 22 /$ ha to $\$ 79 /$ ha to treat with $A V$ 1011 , respectively. Use of hybrid seed rates would make AV1011 cost-effective for growers when protecting drill-planted rice.

Based on our results and the extent of economic loss to rice growers, the EPA granted an emergency use Section 18 application for use of AV-1011 on drill-planted rice in Louisiana, Missouri, and Texas, which will provide an opportunity to evaluate AV-1011 on a large scale. Additional testing should be conducted to determine efficacy of lower concentrations to make the product more cost-effective at various seeding application rates and determine efficacy of AV-1011 for protecting water seeded and ripening rice.

\section{ACKNOWLEDGMENTS}

Funding for this project was provided by M. Braverman (Biopesticide Program, Rutgers University). We thank K. Ballinger (Arkion ${ }^{\text {TM }}$ Life Sciences LLC). We thank the NWRC Analytical Chemistry Project for analyzing rice samples for AQ residues. Use of a company or trade name does not imply United States Government endorsement of commercial products. We also thank M.E. Tobin, M. Braverman, and J.E. Spykstra for constructive review of this study.

\section{LITERATURE CITED}

Association of Official Seed Analysts, 1981. Rules for testing seed. Journal of Seed Technology 6(2) 1-162.

Avery, M. L. 2002. Behavioral and ecological considerations for managing bird damage to cultivated fruit. Pages 467-477 in D. J. Levey, W. R. Silva, and M., Galetti, editors. Seed disposal and frugivory: ecology, evolution and conservation. CAB International, Oxon, United Kingdom.

Avery, M. L., and J. L. Cummings. 2003. Chemical repellents for reducing crop damage by blackbirds. Pages 41-48 in G. M. Linz, editor. Management of North American blackbirds. National Wildlife Research Center, Fort Collins, Colorado, USA.

Avery, M. L., J. S. Humprey, and D. G. Decker. 1997. Feeding deterrence of Anthraquinone, Anthracene, and Anthrone to rice-eating birds. Journal of Wildlife Management 61:1359-1365.

Avery, M. L., J. S. Humprey, T. M. Primus, D. G. Decker, and A. P. McGrane. 1998. Anthraquinone protects rice seed from birds. Crop Protection 17:225-230.

Cummings, J. L., D. L. Otis, and J. E. Davis, Jr. 1992. Dimethyl and methyl anthranilate and methiocarb deter feeding in captive Canada geese and mallards. Journal of Wildlife Management 56:349-355.

Cummings, J. L., J. R. Mason, D. L. Otis, J. E. Davis, Jr. and T. Ohashi. 1994. Evaluation of methiocarb, ziram, and methyl anthranilate as bird repellents applied to dendrobium orchids. Wildlife Society Bulletin 22:633-638.

Cummings, J. L., P. A. Pochop, R. M. Engeman, J. E. Davis, Jr., and T. M. Primus. 2002. Evaluation of Flight Control ${ }^{\mathbb{R}}$ to reduce blackbird damage to newly planted rice in Louisiana. International Biodeterioration and Biodegradation 49:169-173.

Cummings, J. L., S. A. Shwiff, and S. K. Tupper. 2005. Economic impacts of blackbirds on newly planted and ripening rice. Wildlife Damage Management Conference 11:317-322.

Dolbeer, R. A., N. R. Holler, and D. W. Hawthorne. 1994. Identification and control of wildlife damage. Pages 474-506 in T. A. Bookhout, editor. Research and management techniques for wildlife and habitats. The Wildlife Society, Bethesda, Maryland, USA.

Environmental Protection Agency. 1998. Biopesticide fact sheet. Anthraquinone Environmental Protection Agency, Washington, D.C., USA.

Hilker, M., and A. Kopf. 1994. Evaluation of the palatability of chrysomelid larvae containing anthraquinone to birds. Oecologia 100:421-429.

SAS Institute, Inc. 2003. SAS/STAT User's Guide, Volume 3. SAS Institute, Inc. Cary, North Carolina, USA.

U.S. Department of Agriculture National Agricultural Statistics Service. 2008. U.S. Rice Statistics. <http://www.nass.usda.gov/index.asp> Accessed 1 Jun 2010.

Werner, S. J., J. L. Cummings, S. K. Tupper, D. A. Goldade, and D. Beighley. 2008a. Blackbird repellency of selected registered pesticides. Journal of Wildlife Management 72:1007-1011.

Werner, S. J., J. L. Cummings, P. A. Pipas, S. K. Tupper, and R. W. Byrd. 2008b. Registered pesticides and citrus terpenes as blackbird repellents for rice. Journal of Wildlife Management 72:1863-1868.

Associate Editor: Terry A. Messmer. 